\title{
Predictors of miscarriage: a matched case-control study
}

\author{
Jalal Poorolajal ${ }^{1}$, Parvin Cheraghi ${ }^{2}$, Zahra Cheraghi $^{3}$, Masoomeh Ghahramani ${ }^{4}$, Amin Doosti Irani $^{3}$ \\ ${ }^{1}$ Modeling of Noncommunicable Diseases Research Center and Department of Epidemiology and Biostatistics, School of Public Health, \\ Hamadan University of Medical Sciences, Hamadan; ${ }^{2}$ Department of Health Education and Promotion, School of Public Health, Hamadan \\ University of Medical Sciences, Hamadan; ${ }^{3}$ Department of Epidemiology and Biostatistics, School of Public Health, Tehran University of \\ Medical Sciences, Tehran; ${ }^{4}$ Vice-Chancellor of Health Services, Hamadan University of Medical Sciences, Hamadan, Iran
}

OBJECTIVES: The risk factors for miscarriage vary across communities and countries. This study was conducted to investigate the predictors of miscarriage in the west of Iran.

METHODS: This matched case-control study was conducted in Hamadan Province from April 2013 to March 2014. Cases were selected from women who had a recent spontaneous abortion and controls were selected from women who had a recent live birth. Two controls were selected for every case and matched for date of pregnancy and area of residence. Multivariate conditional logistic regression analysis was performed and odds ratios (ORs) and 95\% confidence intervals (CIs) were calculated.

RESULTS: Five hundred fifty cases were compared with 1,091 controls. The OR of miscarriage was 1.58 (95\% $\mathrm{CI}=1.30-1.92)$ for every five-year increase in age, 0.20 (95\% CI=0.14-0.28) for every live birth, and 3.43 (95\% CI $=2.03-5.79)$ for a history of previous spontaneous abortion. Compared to nulliparous women, primiparous or multiparous women had an OR of $17.85(95 \% \mathrm{CI}=6.65-47.91)$ for miscarriage. There was a strong association between miscarriage and abnormal amniotic status (OR, 2.46; 95\% CI, 0.46-13.09) and also abnormal placenta status (OR, 10.44; 95\% CI, 0.95-114.92); however, these associations were not statistically significant. No significant associations were observed between miscarriage and body mass index, previous history of stillbirth, low birth weight, congenital anomaly, ectopic pregnancy, impaired thyroid function, or high blood pressure.

CONCLUSIONS: Our study suggests that miscarriage is a multifactorial outcome associated with several modifiable and non-modifiable risk factors that may vary among different communities.

KEY WORDS: Spontaneous abortion, Habitual abortion, Risk factors, Case-control studies, Iran

\section{INTRODUCTION}

Abortion is an important cause of morbidity and mortality among women of reproductive age, particularly in developing countries $[1,2]$. Abortion is defined as the removal of products

\author{
Correspondence: Parvin Cheraghi \\ Department of Health Education and Promotion, School of Public Health, \\ Hamadan University of Medical Sciences, Shahid Fahmideh Ave., Hamadan \\ 6517838695, Iran \\ Tel: +98-811-8380090, Fax: +98-811-8380509, \\ E-mail: parvin.cheraghi@umsha.ac.ir \\ Received: Oct 20, 2014, Accepted: Nov 20, 2014, Published: Nov 20, 2014 \\ This article is available from: http://e-epih.org/ \\ (C) 2014, Korean Society of Epidemiology \\ (C) This is an open-access article distributed under the terms of the Creative Commons \\ Attribution License (http://creativecommons.org/licenses/by/3.0/), which permits \\ unrestricted use, distribution, and reproduction in any medium, provided the original \\ work is properly cited.
}

of conception from the uterus when the fetus is not viable, before the 20th week of pregnancy [3]. An alternative definition is delivery of a fetus with a weight of less than $500 \mathrm{~g}$ [4]. Abortion is either spontaneous or induced.A spontaneous abortion, or miscarriage, is the natural death of a fetus in the womb. Miscarriage is the most common complication of early pregnancy in humans [5] with a rate of $15-20 \%$ among pregnant women [6].

Approximately $80 \%$ of miscarriages occur in the first trimester [7]. Genetic abnormalities, maternal disorders, and cardiovascular diseases are among the known reasons for miscarriage [8]. Lifestyle, diet, smoking, and alcohol are other probable risk factors for miscarriage $[9,10]$. In some studies, obesity has been introduced as an independent risk factor for miscarriage [11].A maternal age of 35 or above plays an important role in the incidence of miscarriage [12]. A history of previous miscarriage and ectopic pregnancy can increase the risk of miscarriage [13]. When 
a miscarriage occurs, it is followed by a number of complications such as infection (48\%), bleeding (21\%), embolism (11\%), and a number of physical problems [7].

Several studies have been conducted worldwide to assess the incidence rate of miscarriage and its associated predictors [813]. Despite the impact of several known risk factors on miscarriage, the reasons for 30 to $50 \%$ of miscarriages are unknown [8]. Furthermore, the predictors of miscarriage have not been properly investigated in low- and middle-income countries. The only information comes from small, unrepresentative samples addressing a limited number of risk factors. Until reliable information on the predictors of miscarriage is collected, it is difficult to design effective preventive intervention strategies. Accordingly, we conducted this matched case-control study in the west of Iran, in which we measured the effect of several potential risk factors on miscarriage. In this paper, we report the results of univariate and multivariate conditional logistic regression analyses of the predictors of miscarriage.

\section{MATERIALSAND METHODS}

This matched case-control study was conducted in Hamadan Province from April 2013 to March 2014. The Research Council of Hamadan University of Medical Sciences approved the study. Hamadan Province includes nine cities with a population of $1,819,777$ people. In this province, there are 163 health centers, including 93 rural and 70 urban health centers [14]. Women refer to these health centers for periodic checkups during pregnancy. A health record is maintained for every pregnant woman. The health records include the results of medical history taking, physical examination, and routine laboratory tests during pregnancy. The study population included women of reproductive age with at least one pregnancy that had written health records in the rural or urban health centers of the province. Women whose health records were incomplete and those who had a history of induced abortion or extramarital pregnancy were excluded from the study.

Cases were selected from women who had a recent spontaneous abortion and controls were selected from the women who had a recent live birth. All eligible spontaneous abortions, occurred during the study period, were enrolled into the study. Two controls for every case were randomly selected from the same health care records. Controls were individually matched to cases by date of pregnancy and area of residence.

Data collection was carried out using a checklist of items that was developed according to the information in the written health care records. Body mass index (BMI), the weight in kilograms divided by the square of the height in meters $\left(\mathrm{kg} / \mathrm{m}^{2}\right)$, was classified according to the World Health Organization guideline [15] as follows: a BMI less than $18.5 \mathrm{~kg} / \mathrm{m}^{2}$ is underweight, a BMI greater than or equal to $18.5 \mathrm{~kg} / \mathrm{m}^{2}$ is normal weight, a BMI greater than or equal to $25 \mathrm{~kg} / \mathrm{m}^{2}$ is overweight, and a BMI greater than or equal to $30 \mathrm{~kg} / \mathrm{m}^{2}$ is obese. A stillbirth was defined the birth of a baby with no signs of life at or after 20 weeks' gestation [16]. A birth weight of a live born infant of less than 2,500 $\mathrm{g}$, regardless of gestational age, was defined as low birth weight (LBW) [17], and a birth weight of more than 4,000 $\mathrm{g}$ as high birth weight (HBW) [18]. A woman who had never carried a pregnancy beyond 20 weeks was defined nulliparous, a woman who had given birth once before was defined as primiparous, and a woman who had given birth two or more times was defined as multiparous [19]. Too much or too little amniotic fluid was considered abnormal amniotic fluid [20]. Placental abnormalities included 'placenta previa' (a condition in which the placenta is abnormally placed, and partially or totally covers the cervix) and 'placental abruption' (a condition in which the placenta separates from the wall of the uterus prior to the birth of the baby) [21].

Conditional logistic regression analysis was performed to assess the effect of various risk factors on miscarriage. In addition, to control the effect of potential confounding factors, a backward stepwise-adjusted analysis was performed to fit the data well and to exclude unnecessary variables from the model. For this purpose, we started with the full model and then excluded variables one at a time, while checking via the likelihood ratio test whether the reduced model or the full model fitted the data significantly well. Crude and adjusted odds ratios (ORs) were reported to address the associations between miscarriage and the predictors. Alpha was set at a level of 0.05. Analysis was performed using Stata version 11 (StataCorp, College Station, TX, USA).

\section{RESULTS}

During the study period, 550 miscarriages were diagnosed. Two controls with the same time of pregnancy and area of residence were selected for every case. For nine cases, only one control was assigned. Therefore, a total of 1,091 controls was selected and compared with the relevant cases. The mean (standard deviation) age of the cases and controls was 30.35 (5.99) and 28.69 (5.61) years respectively. The characteristics of the study population are given in Table 1.

Results from the bivariate conditional logistic regression analysis of several binary and continuous predictors of miscarriage are given in Table 2. According to the results, there was a direct association between miscarriage and age so that the OR of miscarriage increased by $1.30(95 \% \mathrm{CI}=1.19-1.43)$ for every five years. On the other hand, there was an inverse association be- 
Table 1. Characteristics of the study population

\begin{tabular}{|c|c|c|c|}
\hline Variable & $\begin{array}{c}\text { Controls } \\
(n=1,091)\end{array}$ & $\begin{array}{c}\text { Cases } \\
(n=550)\end{array}$ & $\begin{array}{c}\text { Total } \\
(n=1,641)\end{array}$ \\
\hline $\begin{array}{l}\text { Age (yr) } \\
16-20 \\
21-25 \\
26-30 \\
31-35 \\
36-40 \\
41-47\end{array}$ & $\begin{array}{r}78 \\
252 \\
347 \\
260 \\
121 \\
15\end{array}$ & $\begin{array}{r}17 \\
109 \\
165 \\
129 \\
93 \\
28\end{array}$ & $\begin{array}{r}95 \\
361 \\
512 \\
389 \\
214 \\
43\end{array}$ \\
\hline $\begin{array}{l}\text { Educational level } \\
\text { Tertiary } \\
\text { High school } \\
\text { Secondary school } \\
\text { Primary school }\end{array}$ & $\begin{array}{r}64 \\
298 \\
284 \\
444\end{array}$ & $\begin{array}{r}25 \\
147 \\
131 \\
247\end{array}$ & $\begin{array}{r}89 \\
445 \\
415 \\
691\end{array}$ \\
\hline $\begin{array}{l}\text { Previous spontaneous abortior } \\
\text { No } \\
\text { Yes }\end{array}$ & $\begin{array}{l}976 \\
115\end{array}$ & $\begin{array}{l}350 \\
200\end{array}$ & $\begin{array}{r}1,326 \\
315\end{array}$ \\
\hline $\begin{array}{l}\text { Previous ectopic pregnancy } \\
\text { No } \\
\text { Yes }\end{array}$ & $\begin{array}{r}1,084 \\
3\end{array}$ & $\begin{array}{r}537 \\
7\end{array}$ & $\begin{array}{r}1,621 \\
10\end{array}$ \\
\hline $\begin{array}{l}\text { Amniotic status } \\
\text { Normal } \\
\text { Abnormal }\end{array}$ & $\begin{array}{r}1,077 \\
11\end{array}$ & $\begin{array}{r}280 \\
12\end{array}$ & $\begin{array}{r}1,357 \\
23\end{array}$ \\
\hline $\begin{array}{l}\text { Placenta status } \\
\text { Normal } \\
\text { Abnormal }\end{array}$ & $\begin{array}{r}1,084 \\
5\end{array}$ & $\begin{array}{r}283 \\
11\end{array}$ & $\begin{array}{r}1,367 \\
16\end{array}$ \\
\hline $\begin{array}{l}\text { Body mass index }\left(\mathrm{kg} / \mathrm{m}^{2}\right) \\
\text { Underweight }(<18.5) \\
\text { Normal weight }(18.5-24.9) \\
\text { Overweight }(25.0-29.9) \\
\text { Obese }(\geq 30.0)\end{array}$ & $\begin{array}{l}102 \\
602 \\
217 \\
129\end{array}$ & $\begin{array}{r}36 \\
306 \\
108 \\
83\end{array}$ & $\begin{array}{l}138 \\
908 \\
325 \\
212\end{array}$ \\
\hline $\begin{array}{l}\text { Parity } \\
\text { Nulliparous } \\
\text { Primiparous or multiparous }\end{array}$ & $\begin{array}{l}164 \\
927\end{array}$ & $\begin{array}{r}12 \\
538\end{array}$ & $\begin{array}{r}176 \\
1,465\end{array}$ \\
\hline $\begin{array}{l}\text { Gravidity } \\
1 \text { or } 2 \\
3 \\
4 \\
5+\end{array}$ & $\begin{array}{r}707 \\
280 \\
69 \\
35\end{array}$ & $\begin{array}{r}304 \\
156 \\
67 \\
23\end{array}$ & $\begin{array}{r}1,011 \\
436 \\
136 \\
58\end{array}$ \\
\hline $\begin{array}{l}\text { Number of live births } \\
0 \\
1 \\
2 \\
3 \\
4\end{array}$ & $\begin{array}{r}58 \\
357 \\
447 \\
194 \\
35\end{array}$ & $\begin{array}{r}57 \\
335 \\
132 \\
20 \\
6\end{array}$ & $\begin{array}{r}115 \\
692 \\
579 \\
214 \\
41\end{array}$ \\
\hline $\begin{array}{l}\text { Interval between pregnancies } \\
\geq 3 \\
<3\end{array}$ & i) $\begin{array}{r}1,004 \\
84\end{array}$ & $\begin{array}{r}487 \\
57\end{array}$ & $\begin{array}{r}1,491 \\
141\end{array}$ \\
\hline $\begin{array}{l}\text { Previous twin birth } \\
\text { No } \\
\text { Yes }\end{array}$ & $\begin{array}{r}1,083 \\
8\end{array}$ & $\begin{array}{r}543 \\
7\end{array}$ & $\begin{array}{r}1,626 \\
15\end{array}$ \\
\hline $\begin{array}{l}\text { Previous stillbirth } \\
\text { No } \\
\text { Yes }\end{array}$ & $\begin{array}{r}1,066 \\
22\end{array}$ & $\begin{array}{r}524 \\
20\end{array}$ & $\begin{array}{r}1,590 \\
42\end{array}$ \\
\hline $\begin{array}{l}\text { Previous low birth weight }(<2, \\
\text { No } \\
\text { Yes }\end{array}$ & $\begin{array}{r}00 \mathrm{~g}) \\
1,059 \\
29\end{array}$ & $\begin{array}{r}524 \\
21\end{array}$ & $\begin{array}{r}1,583 \\
50\end{array}$ \\
\hline $\begin{array}{l}\text { Previous high birth weight ( }>4 \\
\text { No } \\
\text { Yes }\end{array}$ & $\begin{array}{r}00 \text { g) } \\
1,075 \\
12\end{array}$ & $\begin{array}{r}536 \\
9\end{array}$ & $\begin{array}{r}1,611 \\
21\end{array}$ \\
\hline $\begin{array}{l}\text { Previous congenital anomaly } \\
\text { No } \\
\text { Yes }\end{array}$ & $\begin{array}{r}1,075 \\
12\end{array}$ & $\begin{array}{r}533 \\
11\end{array}$ & $\begin{array}{r}1,608 \\
23\end{array}$ \\
\hline $\begin{array}{l}\text { Impaired thyroid function } \\
\text { No } \\
\text { Yes }\end{array}$ & $\begin{array}{r}1,048 \\
39\end{array}$ & $\begin{array}{r}523 \\
22\end{array}$ & $\begin{array}{r}1,571 \\
61\end{array}$ \\
\hline $\begin{array}{l}\text { High blood pressure } \\
\text { No } \\
\text { Yes }\end{array}$ & $\begin{array}{r}1,066 \\
21\end{array}$ & $\begin{array}{r}540 \\
5\end{array}$ & $\begin{array}{r}1,606 \\
26\end{array}$ \\
\hline $\begin{array}{l}\text { Sex of fetus } \\
\text { Male } \\
\text { Female }\end{array}$ & $\begin{array}{l}570 \\
496\end{array}$ & $\begin{array}{l}43 \\
35\end{array}$ & $\begin{array}{l}613 \\
531\end{array}$ \\
\hline
\end{tabular}

tween miscarriage and educational level, such that the lower the educational level, the higher the risk of miscarriage. However, this association was not statistically significant. The OR of miscarriage was $5.40(95 \% \mathrm{CI}=4.03-7.24)$ for those women with a history of previous spontaneous abortion and 4.67 (95\% $\mathrm{CI}=1.21-18.05)$ for those with a history of previous ectopic pregnancy. Abnormal amniotic fluid and placental abnormalities were two strong predictors of miscarriage. The OR of miscarriage was $4.80(95 \% \mathrm{CI}=1.69-13.62)$ and $20.54(95 \% \mathrm{CI}=$ 2.64-159.75), for previous history of abnormal amniotic fluid and placental abnormalities, respectively. Compared to nulliparous women, primiparous or multiparous women had an OR of $10.06(95 \% \mathrm{CI}=5.37-18.88)$ for miscarriage. The OR of miscarriage was $5.40(95 \% \mathrm{CI}=4.03-7.24)$ for women with a history of spontaneous abortion. There was a direct association between miscarriage and BMI. The OR corresponding to an increase in BMI from underweight to normal weight, or from normal weight to overweight, or from overweight to obese, was 1.15 (95\% CI=1.01-1.31). The risk of miscarriage increased with the number of previous pregnancies but decreased with the number of previous live births. An interval between pregnancies of less than three years and a previous history of twin birth, still birth, LBW, HBW, or congenital anomalies increased the risk of miscarriage, but these associations were not statistically significant. There was no significant association between miscarriage and maternal impaired thyroid function or high blood pressure. The gender of the fetus had no significant effect on miscarriage.

Results from the multiple conditional logistic regression analysis of binary and continuous predictors of miscarriage, adjusted for all other variables in the model, are given in Table 3. There was a gradient of risk within the age groups, such that the OR of miscarriage increased by 1.58 (95\% CI=1.30-1.92) for every five-year increase in age, after controlling for the other variables in the model. There was an inverse association between miscarriage and the number of live births such that the OR of miscarriage decreased by $0.20(95 \% \mathrm{CI}=0.14-0.28)$ for every live birth. A history of previous spontaneous abortion increased the risk of miscarriage by $3.43(95 \% \mathrm{CI}=2.03-5.79)$. Compared to nulliparous women, primiparous or multiparous women had an OR of 17.85 (95\% CI=6.65-47.91) for miscarriage. The OR of miscarriage associated with abnormal amniotic status was 2.46 (95\% CI= 0.46-13.09) compared to normal status, although this association was not statistically significant $(\mathrm{p}=0.293)$. In addition, the OR associated with abnormal placenta status was 10.44 (95\% CI=0.95-114.92) compared to normal status, although this association was also not statistically significant $(\mathrm{p}=0.055)$. 
Table 2. Results from bivariate conditional logistic regression analyses of several binary and continuous predictors of miscarriag

\begin{tabular}{|c|c|c|c|c|}
\hline Variable & Controls $(n=1,091)$ & Cases $(n=550)$ & Odds ratio (95\% confidence interval) & p-value \\
\hline $\begin{array}{l}\text { Age }(\mathrm{yr}) \\
16-20 \\
21-25 \\
26-30 \\
31-35 \\
36-40 \\
41-47 \\
\text { Per five years' increase in age }\end{array}$ & $\begin{array}{r}78 \\
252 \\
347 \\
260 \\
121 \\
15 \\
1,073\end{array}$ & $\begin{array}{r}17 \\
109 \\
165 \\
129 \\
93 \\
28 \\
541\end{array}$ & $\begin{array}{l}\quad 1.00 \\
2.15(1.18-3.92) \\
2.43(1.35-4.37) \\
2.60(1.42-4.75) \\
4.01(2.13-7.53) \\
9.09(3.70-21.18) \\
1.30(1.19-1.43)\end{array}$ & $\begin{array}{l}0.01 \\
0.003 \\
0.002 \\
0.001 \\
0.001 \\
0.001\end{array}$ \\
\hline $\begin{array}{l}\text { Educational level } \\
\text { Tertiary } \\
\text { High school } \\
\text { Secondary school } \\
\text { Primary school }\end{array}$ & $\begin{array}{r}64 \\
298 \\
284 \\
444\end{array}$ & $\begin{array}{r}25 \\
147 \\
131 \\
247\end{array}$ & $\begin{array}{c}1.00 \\
1.32(0.79-2.19) \\
1.27(0.74-2.18) \\
1.56(0.92-2.65)\end{array}$ & $\begin{array}{l}0.29 \\
0.38 \\
0.10\end{array}$ \\
\hline $\begin{array}{l}\text { Previous spontaneous abortion } \\
\text { No } \\
\text { Yes }\end{array}$ & $\begin{array}{l}976 \\
115\end{array}$ & $\begin{array}{l}350 \\
200\end{array}$ & $\begin{array}{c}1.00 \\
5.40(4.03-7.24)\end{array}$ & 0.001 \\
\hline $\begin{array}{l}\text { Previous ectopic pregnancy } \\
\text { No } \\
\text { Yes }\end{array}$ & $\begin{array}{r}1,084 \\
3\end{array}$ & $\begin{array}{r}537 \\
7\end{array}$ & $\begin{array}{c}1.00 \\
4.67(1.21-18.05)\end{array}$ & 0.03 \\
\hline $\begin{array}{l}\text { Amniotic status } \\
\text { Normal } \\
\text { Abnormal }\end{array}$ & $\begin{array}{r}1,077 \\
11\end{array}$ & $\begin{array}{r}280 \\
12\end{array}$ & $\begin{array}{c}1.00 \\
4.80(1.69-13.62)\end{array}$ & 0.003 \\
\hline $\begin{array}{l}\text { Placenta status } \\
\text { Normal } \\
\text { Abnormal }\end{array}$ & $\begin{array}{r}1,084 \\
5\end{array}$ & $\begin{array}{r}283 \\
11\end{array}$ & $\begin{array}{c}1.00 \\
20.54(2.64-159.75)\end{array}$ & 0.004 \\
\hline $\begin{array}{l}\text { Body mass index }\left(\mathrm{kg} / \mathrm{m}^{2}\right) \\
\text { Underweight }(<18.5) \\
\text { Normal weight }(18.5-24.9) \\
\text { Overweight }(25.0-29.9) \\
\text { Obese }(\geq 30.0) \\
\text { Per one category up }\end{array}$ & $\begin{array}{r}102 \\
602 \\
217 \\
129 \\
1,050\end{array}$ & $\begin{array}{r}36 \\
306 \\
108 \\
83 \\
533\end{array}$ & $\begin{array}{c}1.00 \\
1.49(0.99-2.26) \\
1.48(0.93-2.34) \\
1.88(1.16-3.06) \\
1.15(1.01-1.31)\end{array}$ & $\begin{array}{l}0.06 \\
0.10 \\
0.01 \\
0.04\end{array}$ \\
\hline $\begin{array}{l}\text { Parity } \\
\text { Nulliparous } \\
\text { Primiparous or multiparous }\end{array}$ & $\begin{array}{l}164 \\
927\end{array}$ & $\begin{array}{r}12 \\
538\end{array}$ & $\begin{array}{c}1.00 \\
10.06(5.37-18.88)\end{array}$ & 0.001 \\
\hline $\begin{array}{l}\text { Gravidity } \\
1 \text { or } 2 \\
3 \\
4 \\
5+ \\
\text { Per one increase in gravity }\end{array}$ & $\begin{array}{r}707 \\
280 \\
69 \\
35 \\
1,091\end{array}$ & $\begin{array}{r}304 \\
156 \\
67 \\
23 \\
550\end{array}$ & $\begin{array}{c}1.00 \\
14.93(7.40-30.12) \\
27.74(12.90-59.66) \\
17.93(7.54-42.61) \\
1.56(1.38,1.76)\end{array}$ & $\begin{array}{l}0.001 \\
0.001 \\
0.001 \\
0.001\end{array}$ \\
\hline $\begin{array}{l}\text { Number of live births } \\
0 \\
1 \\
2 \\
3 \\
4 \\
\text { Per unit increase in live birth }\end{array}$ & $\begin{array}{r}58 \\
357 \\
447 \\
194 \\
35 \\
1,091\end{array}$ & $\begin{array}{r}57 \\
335 \\
132 \\
20 \\
6 \\
550\end{array}$ & $\begin{array}{c}1.00 \\
0.84(0.54-1.31) \\
0.22(0.14-0.36) \\
0.06(0.03-0.12) \\
0.10(0.04-0.28) \\
0.36(0.31-0.43)\end{array}$ & $\begin{array}{l}0.45 \\
0.001 \\
0.001 \\
0.001 \\
0.001\end{array}$ \\
\hline $\begin{array}{l}\text { Interval between pregnancies (yr) } \\
\quad \geq 3 \\
<3\end{array}$ & $\begin{array}{r}1,004 \\
84\end{array}$ & $\begin{array}{r}487 \\
57\end{array}$ & $\begin{array}{c}1.00 \\
1.39(0.96-2.01)\end{array}$ & 0.08 \\
\hline $\begin{array}{l}\text { Previous twin birth } \\
\text { No } \\
\text { Yes }\end{array}$ & $\begin{array}{r}1,083 \\
8\end{array}$ & $\begin{array}{r}543 \\
7\end{array}$ & $\begin{array}{c}1.00 \\
1.83(0.63-5.29)\end{array}$ & 0.26 \\
\hline $\begin{array}{l}\text { Previous stillbirth } \\
\text { No } \\
\text { Yes }\end{array}$ & $\begin{array}{r}1,066 \\
22\end{array}$ & $\begin{array}{r}524 \\
20\end{array}$ & $\begin{array}{c}1.00 \\
1.85(1.00-3.42)\end{array}$ & 0.05 \\
\hline $\begin{array}{l}\text { Previous low birth weight }(<2,500 \mathrm{~g}) \\
\text { No } \\
\text { Yes }\end{array}$ & $\begin{array}{r}1,059 \\
29\end{array}$ & $\begin{array}{r}524 \\
21\end{array}$ & $\begin{array}{c}1.00 \\
1.48(0.81-2.69)\end{array}$ & 0.20 \\
\hline $\begin{array}{l}\text { Previous high birth weight }(>4,000 \mathrm{~g}) \\
\text { No } \\
\text { Yes }\end{array}$ & $\begin{array}{r}1,075 \\
12\end{array}$ & $\begin{array}{r}536 \\
9\end{array}$ & $\begin{array}{c}1.00 \\
1.50(0.63-3.56)\end{array}$ & 0.36 \\
\hline $\begin{array}{l}\text { Previous congenital anomaly } \\
\text { No } \\
\text { Yes }\end{array}$ & $\begin{array}{r}1,075 \\
12\end{array}$ & $\begin{array}{r}533 \\
11\end{array}$ & $\begin{array}{c}1.00 \\
1.83(0.81-4.15)\end{array}$ & 0.15 \\
\hline $\begin{array}{l}\text { Impaired thyroid function } \\
\text { No } \\
\text { Yes }\end{array}$ & $\begin{array}{r}1,048 \\
39\end{array}$ & $\begin{array}{r}523 \\
22\end{array}$ & $\begin{array}{c}1.00 \\
1.12(0.65-1.93)\end{array}$ & 0.67 \\
\hline $\begin{array}{l}\text { High blood pressure } \\
\text { No } \\
\text { Yes }\end{array}$ & $\begin{array}{r}1,066 \\
21\end{array}$ & $\begin{array}{r}540 \\
5\end{array}$ & $\begin{array}{c}1.00 \\
0.42(0.15-1.16)\end{array}$ & 0.10 \\
\hline $\begin{array}{l}\text { Sex of fetus } \\
\text { Male } \\
\text { Female }\end{array}$ & $\begin{array}{l}570 \\
496\end{array}$ & $\begin{array}{l}43 \\
35\end{array}$ & $\begin{array}{c}1.00 \\
1.10(0.62-1.99)\end{array}$ & 0.73 \\
\hline
\end{tabular}


Table 3. Results from multivariate conditional logistic regression analyses of binary and continuous predictors of miscarriage, adjusted for all other variables in the model (pseudo $R^{2}=0.4015$ )

\begin{tabular}{|c|c|c|c|c|}
\hline Variable & Controls $(n=1,091)$ & Cases $(n=550)$ & Adjusted odds ratio ( $95 \%$ confidence interval) & p-value \\
\hline \multicolumn{5}{|l|}{ Age (yr) } \\
\hline Per five-year increase in age & 1,073 & 541 & $1.58(1.30-1.92)$ & 0.001 \\
\hline \multicolumn{5}{|l|}{ Number of live births } \\
\hline Per unit increase in live birth & 1,091 & 550 & $0.20(0.14-0.28)$ & 0.001 \\
\hline \multicolumn{5}{|l|}{ Previous spontaneous abortion } \\
\hline No & 976 & 350 & 1.00 & \\
\hline Yes & 115 & 200 & $3.43(2.03-5.79)$ & 0.001 \\
\hline \multicolumn{5}{|l|}{ Parity } \\
\hline Nulliparous & 164 & 12 & 1.00 & \\
\hline Primiparous or multiparous & 927 & 538 & $17.85(6.65-47.91)$ & 0.001 \\
\hline \multicolumn{5}{|l|}{ Amniotic status } \\
\hline Normal & 1,077 & 280 & 1.00 & \\
\hline Abnormal & 11 & 12 & $2.46(0.46-13.09)$ & 0.29 \\
\hline \multicolumn{5}{|l|}{ Placenta status } \\
\hline Normal & 1,084 & 283 & 1.00 & \\
\hline Abnormal & 5 & 11 & $10.44(0.95-114.92)$ & 0.05 \\
\hline
\end{tabular}

\section{DISCUSSION}

Miscarriage is a multifactorial complication that is affected by several risk factors that may vary across communities and countries. This study revealed the crude and adjusted effect of several predictors that may play a role in the incidence of miscarriage. Miscarriage had a direct association with parity but an inverse association with the number of live births. This suggests that the probability of miscarriage in nulliparous women is lower than in primiparous or multiparous women, who may have a history of spontaneous abortion. On the other hand, the probability of miscarriage among women with one or more prior live births is lower than women without any past live births. Patients who have experienced primary miscarriage are more likely to have uterine anomalies, which are a risk factor for miscarriage [22]. We can conclude that a history of previous spontaneous abortion significantly increases the risk of miscarriage, while a history of previous live birth considerably decreases the risk.

According to our results, the risk of miscarriage increases more than 1.5-fold for every five-year increase in maternal age, in line with previous studies that found that advanced maternal age is associated with an increased miscarriage rate [12,23,24]. A multicenter study in Europe found that the risk of miscarriage was higher in women aged $\geq 35$ years and particularly in women aged $>35$ years partnered with a man aged $\geq 40$ years [12].

We found that placenta abnormalities increased the risk of miscarriage by more than tenfold and amniotic abnormalities by approximately 2.5 -fold. Although these associations were not statistically significant, they may be worth taking into consideration in future studies. Such strong associations may not have been statistically significant because placenta and amniotic abnormalities were rare among cases and controls. If the num- ber of these events was larger, the associations might be statistically significant. Previous investigations have indicated that placenta and amniotic abnormalities are associated with an increased risk of miscarriage. A meta-analysis conducted by Saraswat et al. [25] revealed that women with antepartum hemorrhage due to placenta previa were at a higher risk of miscarriage compared to those without bleeding (OR, 1.62; 95\% CI, 1.19-2.22).

We indicated that miscarriage was directly associated with several factors, such as increased BMI, previous history of stillbirth, LBW, HBW, congenital anomaly, ectopic pregnancy, abnormal amniotic fluid or placental abnormalities, impaired thyroid function, and high blood pressure, although these associations were not statistically significant. This may be attributed to the rarity of these predictors in both cases and controls, and in fact many previous investigations have indicated that miscarriage is associated with most of these factors. Elevated BMI is a known risk factor for subsequent miscarriage, and has been associated with various adverse pregnancy outcomes, particularly stillbirth [26,27]. Based on the currently available evidence, there is a clear association between thyroid autoimmunity and miscarriage [28]. A short inter-pregnancy interval has been associated with adverse perinatal and maternal outcomes and is an independent risk factor for preterm delivery and neonatal death in the second birth [29,30]. In addition, current evidence shows that the risk of spontaneous abortion significantly increases following a spontaneous abortion [31].

The main limitation of this study was that measuring the effect of several risk factors on an outcome requires reliable sources of data. We used data recorded in health centers throughout the province. The quality and accuracy of the results depend primarily on the quality of the recorded data, and we were unable to verify the accuracy of the data. This might result in informa- 
tion bias.

Despite this limitation, the current study may have a number of implications for health care policy. First, the major leading causes of miscarriage in the target population have been identified in Iran, a middle-income country. Second, we confirmed several perinatal and maternal predictors that play a role in the incidence of miscarriage. These results may be helpful for policymakers to plan preventive programs and prioritise the reduction of risk factors in order to reduce the burden of miscarriage.

Miscarriage is a multifactorial outcome associated with several modifiable and non-modifiable risk factors that may vary across different communities. High-risk individuals should be advised to have regular antenatal visits.

\section{ACKNOWLEDGEMENTS}

We would like to thank the Vice-Chancellor of Research and Technology, Hamadan University of Medical Sciences, for the approval and support of this study.We also thank the health workers of the Hamadan Province for their collaboration and cooperation with the authors.

This study was funded by theVice-Chancellor of Research and Technology, Hamadan University of Medical Sciences.

\section{CONFLICT OF INTEREST}

The authors have no conflicts of interest to declare for this study.

\section{REFERENCES}

1. World Health Organization. Unsafe abortion: global and regional estimates of the incidence of unsafe abortion and associated mortality in 2008. 6th ed. Geneva: World Health Organization; 2008, p. 13.

2. Motaghi Z, Poorolajal J, Keramat A, Shariati M, Yunesian M, Masoumi SZ. Induced abortion rate in Iran: a meta-analysis. Arch Iran Med 2013;16:594-598.

3. Cunningham F, Leveno K, Bloom S, Hauth J, Rouse D, Spong C, et al. Williams obstetrics. 23rd ed. New York: McGraw-Hill; 2009, p. 661.

4. Katz VL. Spontaneous and recurrent abortion: etiology, diagnosis, treatment. In: Katz VL, Lentz G, Lobo RA, Gershenson D. Comprehensive gynecology. 5th ed. New York: Mosby; 2007, p. 359-390.

5. National Institute for Health and Care Excellence. Ectopic pregnancy and miscarriage: diagnosis and initial management in early pregnancy of ectopic pregnancy and miscarriage; 2012 [cited 2014 Nov 4]. Available from: http://www.nice.org.uk/guidance/cg154/resources/ guidance-ectopic-pregnancy-and-miscarriage-pdf.

6. MedlinePlus. Miscarriage [cited 2014 Dec 1]. Available from: http:// www.nlm.nih.gov/medlineplus/miscarriage.html.
7. Novak E, Berek JS. Novak's gynecology. 13th ed. Philadelphia: Lippincott Williams \& Wilkins; 2002, p. 1067-1083.

8. Bazmi S, Behnoush B, Kiani M, Bazmi E. Comparative study of therapeutic abortion permissions in central clinical department of Tehran Legal Medicine Organization before and after approval of law on abortion in Iran. Iran J Pediatr 2008;18:315-322.

9. Chatenoud L, Parazzini F, di Cintio E, Zanconato G, Benzi G, Bortolus R, et al. Paternal and maternal smoking habits before conception and during the first trimester: relation to spontaneous abortion. Ann Epidemiol 1998;8:520-526.

10. Windham GC, Swan SH, Fenster L. Parental cigarette smoking and the risk of spontaneous abortion. Am J Epidemiol 1992;135:13941403.

11. Frøen JF, Arnestad M, Frey K, Vege A, Saugstad OD, Stray-Pedersen B. Risk factors for sudden intrauterine unexplained death: epidemiologic characteristics of singleton cases in Oslo, Norway, 1986-1995. Am J Obstet Gynecol 2001;184:694-702.

12. de la Rochebrochard E1, Thonneau P. Paternal age and maternal age are risk factors for miscarriage; results of a multicentre European study. Hum Reprod 2002;17:1649-1656.

13. Leridon H. Facts and artifacts in the study of intra-uterine mortality: a reconsideration from pregnancy histories. Popul Stud (Camb) 1976; 30:319-335.

14. Hamadan University of Medical Sciences. Health network development [cited 2014 Dec 19]. Available from: http://mboh.umsha.ac.ir/ uploads/akharin\%20vaziyt\%20vahed\%20tabe.pdf (Persian).

15. World Health Organization. 10 facts on obesity; 2014 [cited 2014 Dec 3]. Available from: http://www.who.int/features/factfiles/obesity/en/.

16. MedicineNet. Definition of stillbirth [cited 2014 Oct 10]. Available from: http://www.medicinenet.com/script/main/art.asp?articlekey= 19817.

17. Wikipedia. Low birth weight [cited 2014 Oct 10]. Available from: http://en.wikipedia.org/wiki/Low_birth_weight.

18. Center for Diseases Control and Prevention. PedNSS health indicators [cited 2014 Oct 10]. Available from: http://www.cdc.gov/pednss/ what_is/pednss_health_indicators.htm.

19. Wikipedia. Gravidity and parity [cited 2014 Oct 10]. Available from: http://en.wikipedia.org/wiki/Gravidity_and_parity.

20. Wikipedia. Amniotic fluid index [cited 2014 Oct 14]. Available from: http://en.wikipedia.org/wiki/Amniotic fluid_index.

21. Wolters Kluwer. UpToDate: placental abnormalities; 2014 [cited 2014 Dec 19]. Available from: http://www.uptodate.com/contents/se arch?search=placental+abnormalities\&autoComplete=true.

22. Jaslow CR, Kutteh WH. Effect of prior birth and miscarriage frequency on the prevalence of acquired and congenital uterine anomalies in women with recurrent miscarriage: a cross-sectional study. Fertil Steril 2013;99:1916-1922.e1.

23. De La Rochebrochard E, Thonneau P. Paternal age: are the risks of infecundity and miscarriage higher when the man is aged 40 years or over? Rev Epidemiol Sante Publique 2005;53 Spec No 2:2S47-2S55.

24. Belloc S, Cohen-Bacrie P, Benkhalifa M, Cohen-Bacrie M, De Mouzon J, Hazout A, et al. Effect of maternal and paternal age on pregnancy and miscarriage rates after intrauterine insemination. Reprod Biomed Online 2008;17:392-397.

25. Saraswat L, Bhattacharya S, Maheshwari A, Bhattacharya S. Maternal and perinatal outcome in women with threatened miscarriage in the first trimester: a systematic review. BJOG 2010;117:245-257.

26. Bell R. Maternal body mass index increasing above 20 is associated with increased risk of miscarriage, stillbirth, neonatal death and postneonatal death. Evid Based Med 2014;19:237-238.

27. Boots CE, Bernardi LA, Stephenson MD. Frequency of euploid mis- 
carriage is increased in obese women with recurrent early pregnancy loss. Fertil Steril 2014;102:455-459.

28. Chen L, Hu R. Thyroid autoimmunity and miscarriage: a meta-analysis. Clin Endocrinol (Oxf) 2011;74:513-519.

29. Shachar BZ, Lyell DJ. Interpregnancy interval and obstetrical complications. Obstet Gynecol Surv 2012;67:584-596.
30. Smith GC, Pell JP, Dobbie R. Interpregnancy interval and risk of preterm birth and neonatal death: retrospective cohort study. BMJ 2003; 327:313.

31. Hathout H, Kasrawi R, Moussa MA, Saleh AK. Influence of pregnancy outcome on subsequent pregnancy. Int J Gynaecol Obstet 1982; 20:145-147. 